\title{
The prevalence of hepatitis $C$ and $B$ among patients on hemodialysis and on renal transplantation waiting list in Poland has significantly decreased during the last 10 years
}

\author{
Jolanta Malyszko ${ }^{1}$ Jacek Zawierucha ${ }^{2} \cdot$ Wojciech Marcinkowski ${ }^{2} \cdot$ Tomasz Prystacki $^{2} \cdot$ Teresa Dryl-Rydzynska $^{2}$. \\ Jacek S. Malyszko ${ }^{3}$. Joanna Matuszkiewicz-Rowinska ${ }^{1}$
}

Received: 5 May 2018 / Accepted: 15 May 2018 / Published online: 4 June 2018

(c) The Author(s) 2018

Hepatitis B virus (HBV) and hepatitis C (HCV) infections are a global public health problem.

Approximately 2 billion people worldwide have evidence of past or present infection with $\mathrm{HBV}$, and it is estimated that 248 million individuals are chronic carriers [i.e., positive for hepatitis B surface antigen (HBsAg)] [1]. Prevalence of $\mathrm{HBsAg}$ is reported to be $3.6 \%$; however, it varies depending upon the geographic area. Roughly 600,000 die annually from HBV-related liver disease [1]. HBsAg positivity rates in dialysis patients, although significantly decreased over the several years, correlate with endemicity in the general population with $1 \%$ in US [2] through 1.3-14.6\% in Asian Pacific countries [3]. On the other hand, it is estimated that 130-150 million individuals worldwide (representing 2-3\% of the world population) are chronically infected with $\mathrm{HCV}$ and that 350,000-500,000 of these die each year from longterm complications of this infection, i.e., cirrhosis and hepatocellular carcinoma $[4,5]$. The prevalence of $\mathrm{HCV}$ among patients with chronic kidney disease (CKD) is substantially higher than in the general population, ranging from 10 to $50 \%$, depending on the geographical area [6] (e.g., 7-40\% in developed countries [7] and 3-20\% in Western European countries [8]). Recently, Goodkin and Bieber [9] described the international prevalence of HCV among hemodialysis patients awaiting transplantation. In the Dialysis Outcomes and Practice Patterns Study (DOPPS) database, this

Jolanta Malyszko

jolmal@poczta.onet.pl

1 Department of Nephrology, Dialysis and Internal Medicine, Warsaw Medical University, Banacha 1a, 02-097 Warsaw, Poland

2 Fresenius Medical Care, Poznan, Poland

3 1st Department of Nephrology and Transplantology with Dialysis Unit, Medical University, Białystok, Poland prevalence varied from 0 in China and France to $4.8 \%$ in the US and to $11 \%$ in the Gulf Cooperation Council countries.

In 2017, we conducted a study on 300 potential kidney transplant recipients from 26 dialysis centers in Poland, representing $9.7 \%$ of all dialysis patients in these units [10]. We found that hepatitis B virus (HBV) and HCV taken together were more prevalent in patients on the inactive waiting list compared to those on the active list (3.0 vs. $1.5 \%, p<0.05$ ). We also looked at the prevalence of $\mathrm{HBV}$ and $\mathrm{HCV}$, as well as that of anti-HBc antibodies, in patients from Fresenius Medical Care dialysis units $(n=5890$, representing $1 / 3$ of the whole hemodialysis population in Poland). We then compared the results with similar data from 2007 and with data from the transplantation waiting list in 2017 (Fig. 1). On the waiting list, $\mathrm{HBs}+\mathrm{HBV}-\mathrm{DNA}+$ were found in $0.5 \%$, $\mathrm{HBs}+/ \mathrm{HBV}-\mathrm{DNA}-$ in $0.5 \%$, anti-HCV $-/ \mathrm{HCV}-\mathrm{RNA}+$ in $0.2 \%$, and anti-HBc in $21.1 \%$ of the patients. In 2007, anti$\mathrm{HBc}$ was not tested. According to our results, the prevalence of $\mathrm{HCV}$ in Polish dialysis and waitlisted populations is comparable to that in the general population worldwide [5] and much lower than that in the US [9]. This could be due to the very strict infection control policy in our dialysis units, including the use of separate machines and rooms for $\mathrm{HBV}$ and HCV positive patients, as well for patients with anti-HBc antibodies. It also appears that, thanks to vaccination, the prevalence of HBV has declined. In our population, prevalence of HBV infection was similar to that of US [2], Malaysia and Japan from Asian countries [3], but much lower than in China, Thailand and Korea [3].

With modern treatment of HCV using direct-acting antiviral (DAA) drugs, sustained viral response rate may reach $100 \%$ [11]. Thus, the cure of HCV in CKD stages 4-5, dialysis, and kidney transplant patients now seems possible, and the prevalence of HCV will likely decline rapidly in the near future. Moreover, the option of DAA treatment prior to transplantation has the advantages of shortened waiting 


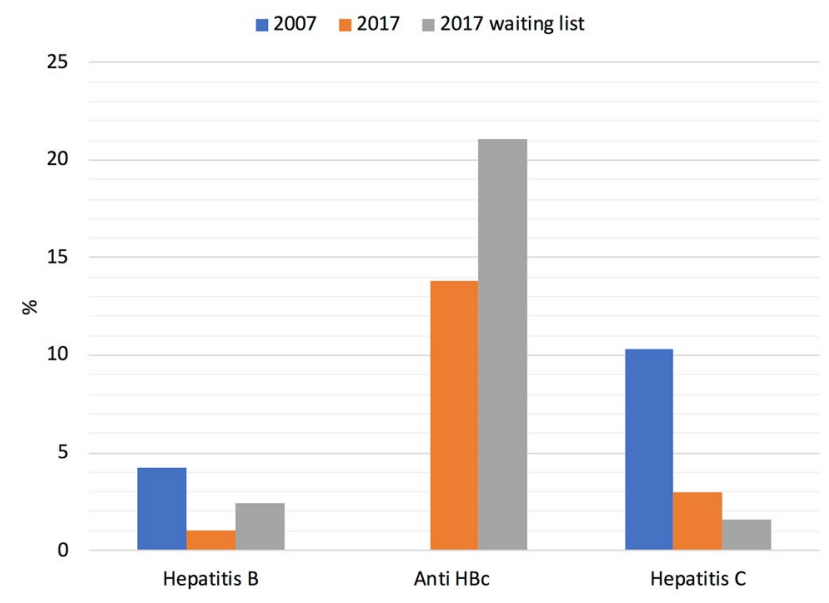

Fig. 1 Prevalence of hepatitis B, hepatitis C, and anti-HBc antibodies (\%) in hemodialyzed patients in 2007 and 2017 and on the waiting list for kidney transplantation in 2017

times and expansion of the organ donor pool to include $\mathrm{HCV}+$ donors [12]. However, there is a risk of DAA interaction with several other drugs, including calcineurin inhibitors [13]; thus, the timing of antiviral therapy for waitlisted patients (before vs after transplantation) should be decided in collaboration with the transplant center.

\section{Compliance with ethical standards}

Conflict of interest The authors declare that they have no conflict of interest.

Ethical approval All procedures performed in studies involving human participants were in accordance with the ethical standards of the institutional research committee and with the 1964 Helsinki Declaration and its later amendments.

Informed consent Informed consent was obtained from all individual participants included in the study.

Open Access This article is distributed under the terms of the Creative Commons Attribution 4.0 International License (http://creativeco mmons.org/licenses/by/4.0/), which permits unrestricted use, distribution, and reproduction in any medium, provided you give appropriate credit to the original author(s) and the source, provide a link to the Creative Commons license, and indicate if changes were made.

\section{References}

1. Schweitzer A, Horn J, Mikolajczyk RT, Krause G, Ott JJ (2013) Estimations of worldwide prevalence of chronic hepatitis B virus infection: a systematic review of data published between 1965 and 2013. Lancet 386:1546-1555

2. Finelli L, Miller JT, Tokars JI, Alter MJ, Arduino MJ (2005) National surveillance of dialysis-associated diseases in the United States, 2002. Semin Dial 18:52-61

3. Johnson DW, Dent H, Yao Q, Tranaeus A, Huang CC, Han DS, Jha V, Wang T, Kawaguchi Y, Qian J (2009) Frequencies of hepatitis $\mathrm{B}$ and $\mathrm{C}$ infections among haemodialysis and peritoneal dialysis patients in Asia-Pacific countries: analysis of registry data. Nephrol Dial Transplant 24:1598-1603

4. WHO Hepatitis C Fact Sheet N 164, http://www.who.int/media centre/factsheets/fs164/en/. Accessed 3 May 2018

5. Polaris Observatory, http://polarisobservatory.org. Accessed 3 May 2018

6. Carvalho-Filho RJ, Feldner AC, Silva AE, Ferraz ML (2015) Management of hepatitis $\mathrm{C}$ in patients with chronic kidney disease. World J Gastroenterol 21:408-422

7. Martin P, Fabrizi F (2008) Hepatitic C virus and kidney disease. J Hepatol 49:613-624

8. Jadoul M, Poignet JL, Geddes C, Locatelli F, Medin C, Krajewska M, Barril G, Scheuermann E, Sonkodi S, Goubau P (2004) HCV Collaborative Group. The changing epidemiology of hepatitis $\mathrm{C}$ virus (HCV) infection in haemodialysis: European multicentre study. Nephrol Dial Transplant 19:904-909

9. Goodkin DA, Bieber B (2018) International prevalence of hepatitis $\mathrm{C}$ positivity among hemodialysis patients awaiting transplantation. Kidney Int 93:1249

10. Malyszko J, Dryl-Rydzynska T, Marcinkowski W, Prystacki T, Malyszko JS (2016) Comorbidities on kidney transplantation waiting list relative to the status of the potential recipient. Arch Med Sci. https://doi.org/10.5114/aoms.2016.60337

11. Sperl J, Kreidlova M, Merta D, Chmelova K, Senkerikova R, Frankova S (2018) Paritaprevir/ritonavir/ombitasvir plus dasabuvir regimen in the treatment of genotype 1 chronic hepatitis $\mathrm{C}$ infection in patients with severe renal impairment and endstage renal disease: a real-life cohort. Kidney Blood Press Res 43:594-605

12. Dejman A, Ladino MA, Roth D (2018) Treatment and management options for the hepatitis $\mathrm{C}$ virus infected kidney transplant candidate. Hemodial Int 22(Suppl 1):S36-S44

13. Jadoul M, Martin P (2017) Hepatitis C treatment in chronic kidney disease patients: the kidney disease improving global outcomes perspective. Blood Purif 43:206-209 